\title{
Clinical Observations Reason Not Done
}

National Cancer Institute

\section{Source}

National Cancer Institute. Clinical Observations Reason Not Done. NCI Thesaurus. Code C119807.

The explanation given as to why a clinical observation was not made. 